\title{
Research on Homeopathy: State of the Art
}

\author{
HARALD WALACH, Ph.D., ${ }^{1-3}$ WAYNE B. JONAS, M.D., Ph.D., ${ }^{3}$ JOHN IVES, Ph.D., ${ }^{3}$ \\ ROEL VAN WIJK, Ph.D., ${ }^{4}$ and OTTO WEINGÄRTNER, Dr.Phil.Nat. ${ }^{5}$
}

\begin{abstract}
In this paper, we review research on homeopathy from four perspectives, focusing on reviews and some landmark studies. These perspectives are laboratory studies, clinical trials, observational studies, and theoretical work. In laboratory models, numerous effects and anomalies have been reported. However, no single model has been sufficiently widely replicated. Instead, researchers have focused on ever-new models and experiments, leaving the picture of scattered anomalies without coherence. Basic research, trying to elucidate a purported difference between homeopathic remedies and control solutions has also produced some encouraging results, but again, series of independent replications are missing. While there are nearly 200 reports on clinical trials, few series have been conducted for single conditions. Some of these series document clinically useful effects and differences against placebo and some series do not. Observational research into uncontrolled homeopathic practice documents consistently strong therapeutic effects and sustained satisfaction in patients. We suggest that this scattered picture has to do with the fourth line of research: lack of a good theory. Some of the extant theoretical models are reviewed, including placebo, water structure, silica contamination, energy models, and entanglement models. It emerges that local models, suggesting some change in structure in the solvent, are far from convincing. The nonlocal models proposed would predict that it is impossible to nail down homeopathic effects with direct experimental testing and this places homeopathy in a scientific dilemma. We close with some suggestions for potentially fruitful research.
\end{abstract}

\section{INTRODUCTION}

$\mathbf{H}$ omeopathy celebrated its 200th anniversary nearly 10 years ago: In 1796, the German physician Samuel Hahnemann, M.D., presented his paper on "A New Principle of Healing," which he termed homeopathy. ${ }^{1,2}$ The name is derived from the Greek words homoion pathos - "similar disease." The name denotes the fact that homeopathy uses substances to cure diseases that are able to produce similar symptoms in healthy persons when ingested by them..$^{3-5}$ This therapeutic principle, to treat likes by likes-similia similibus curentur: let likes be cured by likes-is very old. In fact, it can be located in ancient Greek writings. ${ }^{6}$ The
Myth of Telephos is the first clear trace of it in the West: Telephos was the king of the Mysians, who the Greeks attacked accidentally when they were on their way to raid Troy. Telephos was wounded by the spear of Achilles. And, when the wound did not heal and festered, he asked the Pythia, the prophetess of Delphi, for advice. She gave him the cryptic answer: "Ho trosas kai iasetai"- "He who has slain the wound will cure it again." He then visited Achilles, who brought some of the spear's rust into the wound, which subsequently healed. This first echo of the therapeutic simile principle in the West shows that it is an ancient therapeutic idea. It was taken up by Hippocratic medicine, by Galen and Celsus. It can be found in Paracelsus' work. ${ }^{7}$ It

\footnotetext{
${ }^{1}$ University College Northampton, UK.

${ }^{2}$ University Hospital Freiburg, Germany.

${ }^{3}$ Samueli Institute, Alexandria, VA.

${ }^{4}$ International Institute of Biophysics, Neuss, Germany.

${ }^{5}$ Dr. Reckeweg \& Co. GmbH, Bensheim, Germany.
} 
seems likely that Hahnemann knew of this tradition..$^{8,9}$ But it was his idea to test remedies in healthy volunteers and to note the symptoms as a way to put the simile principle into concrete practice. ${ }^{10}$ These symptoms he then used as indications of remedies in sick people. While the principle of testing remedies was new in Hahnemann's time, other researchers, such as the Swiss physician and researcher von Haller, ${ }^{11}$ had already advocated this. It was Hahnemann's insight to combine the simile principle with testing of medications and to use this information for therapy.

Today, the simile principle is also used in other branches of therapy. ${ }^{12,13}$ Allergology makes use of it in desensitization. Psychotherapy, in some forms, uses the activation of similar situations or constellations of symptoms that produced trouble to cure it.

Hahnemann's unique insight was what he called dynamization or potentization. Although a case can be made that this is an idea that, in principle, has been around at least since Paracelsus, who also spoke of letting the "spirit of substances" free, the practical application by Hahnemann was unique. When he adminstered his remedies to his volunteers, initially his family and students, he soon discovered that crude substances needed dilution because of toxic side-effects. So he started a process of stepwise dilution and succussion. When diluting a substance, after 24 steps in a dilution ratio of $1: 10$ or after 12 steps in a ratio of $1: 100$, a dilution of one mole of starting substance would, by calculation, not have any molecules of the initial substance left. This corresponds to a Hahnemannian dilution of $\mathrm{C} 12$ or $24 \times *$ Beyond this boundary, statistically speaking, none of the starting material remains in a homeopathic remedy.

Avogadro's number refers to the number of molecules in one mole (i.e., $6.023 * 10^{23}$ ). This fact was not known to Hahnemann. Although Hahnemann did not know for sure, he guessed that his dilutions would have very little or none of the starting substance and, therefore, he called his remedies dynamizations or potencies, referring to the paradoxical experience that, with his stepwise process of dilution and succussion, he observed stronger therapeutic effects than with original substances. It is precisely homeopathy's emphasis on so-called high potencies (i.e., remedies succussed and diluted beyond Avogadro's number) that creates tension with modern science because no accepted rational theory exists that could explain increased therapeutic effect with decreasing amounts of the active agent, even to the point of there being no molecules of the initial agent present at all.

In this paper, we wish to point out a few findings from homeopathic research that appear to be robust, delineate areas of contention, and outline potentially fruitful avenues

* "Hahnemannian" here refers to the method of using a fresh vial for every step; frequently, the same glass vial is used for Korsakovian potencies, mainly beyond C200. When using that method, molecules remain longer, through adhesive forces. for research. We do not consider the practical or therapeutic applications and the wide variety thereof. We have organized this brief review in four sections:

1. Experimental research to study the efficacy of homeopathic remedies in vitro, in cell systems, or in vivo

2. Basic research that tries to elucidate the nature of homeopathic remedies

3. Clinical research that tries to find proof of clinical efficacy and experimental research in humans (so called "provings" or pathogenetic trials)

4. Some theoretical models.

Since, in most fields, reviews have been presented and are discussed and referenced elsewhere, ${ }^{14}$ we restrict ourselves to the most outstanding findings and to areas of hot debate.

\section{EXPERIMENTAL RESEARCH}

Historically, homeopaths were among the first to introduce double-blinded experiments in human subjects. ${ }^{15} \mathrm{Ar}-$ guably, among the first experimental models in homeopathy was the one presented by Kolisko who studied the influence of high potencies of silver nitrate (Argentum nitricum) on the growth of plant seedlings, mostly wheat, and found cyclical changes. ${ }^{16-18}$ Some potencies, even beyond Avogadro's number, produced an increase in growth length of seedlings, while other potencies produced a decrease. This experiment has recently been reproduced in blinded fashion, with similar results. ${ }^{19}$ Our own joint attempts, however, were equivocal (data not yet published).

Many plant and animal models have been studied ${ }^{18}$ but only few have been replicated independently, and the quality of the studies is often poor. A review of detoxification paradigms brings them into context. ${ }^{20}$ In this type of experiment, a biologic system-plant or animal-is intoxicated with a substance, and is either pretreated with a homeopathically succussed and diluted substance, or is treated therapeutically after the fact. One hundred and five (105) such experiments were reviewed. The vast majority were of suboptimal quality. Among the high-quality experiments, positive results were reported twice as frequently as negative ones, with an overall positive effect in 4 of 5 experiments and a protection index of roughly $20 \%$. The authors of the review noted that many models exist but only a few replications have been achieved. A more specialized recent review presented studies on agents used in warfare and tolerance-induction via diluted substances and concluded that these models documented some effects of such diluted substances. ${ }^{21} \mathrm{~A}$ full database of all experiments has been compiled by Albrecht and van Wijk and will shortly be available as the HomBRex-Data Base (see www.carstensstiftung.de). ${ }^{22}$ 
One seemingly promising model was developed by French homeopaths. ${ }^{23-26}$ The basic idea is the following: Basophil cells are extracted from the blood of donors. These cells are then stimulated by an antigen, causing them to degranulate. The antigen is diluted and then presented, testing whether the diluted antigen is also active. As a variant model, one can try to prevent degranulation by using another potentized substance (such as potentized histamine) that may inhibit degranulation. In the most recent set of experiments, potentized histamine has been used. A series of experiments was conducted by Benveniste and his laboratory groups, culminating in a final publication postulating the replicability of the effect across laboratories. ${ }^{27}$ This publication was heavily criticized, resulting in independent investigations of the paradigm with no clear-cut reproducible effect, ${ }^{28,29}$ although other experiments, again, yielded positive results. ${ }^{30,31}$ Apparently, even before that, some of the participating laboratories had withdrawn because the effect was not consistent across laboratories. This and similar models were continued by Benveniste later as so-called "digital biology" because he believed that a kind of electromagnetic information was responsible for the effect. He claimed that one could save this information in digital media and play it to a biologic system, with the same effect. ${ }^{32,33}$ Rigorous recent independent replications of this effect with the cooperation of Benveniste's team revealed that the effect is not reproducible but is likely to be the result of a very subtle experimenter effect. ${ }^{34}$

A similar model was presented recently by a multinational group, using roughly the same procedure and reporting an overall significant summary statistic, claiming a reduction of basophil degranulation caused by the application of histamine potentized up to $30 \times$, which is beyond Avogadro's number. ${ }^{35-37}$ An independent group, using the same model but even better methods of identifying the cells, replicated the result. ${ }^{38} \mathrm{~A}$ careful analysis of the studies, however, shows a common pattern in this research. ${ }^{39}$ One laboratory found a reduction of degranulation, while another laboratory saw an increase, and still another laboratory noted no effect. It remains to be seen whether the model will be reproducible and stable in the hands of independent researchers. What we see in these studies has been a recurrent pattern in homeopathy research, with equally intensive attempts at finding stable in vitro models. ${ }^{40-44}$ This pattern is that there are dramatic results, often in the first experimental tests, which are not compatible with random fluctuations only. These results are often also replicable to a certain degree. But rarely are they stable to the degree demanded by mainstream research to accept such phenomena beyond doubt and without a comprehensive theoretical framework.

Another experimental model that has achieved some reputation for replicability is the thyroxin-dependent stimulation of metamorphosis in tadpoles. ${ }^{45-48}$ In that model, tadpole metamorphosis is accelerated by adding thyroxin in a high potency (usually $30 \times$ ). Thyroxin stimulates growth and quickens the metamorphosis from the two-legged stage into the four-legged stage. Potentized thyroxin can produce this effect also and, if potentized thyroxin is administered before a stimulating dose, it can also reverse the effect. This model has been mainly used by one group of researchers but has been partially replicated in several laboratories. However, one completely independent replication failed ${ }^{49}$ and one was positive. ${ }^{50}$ In addition, in one large study, the effect was significant mainly because, in one laboratory, there were very strong effects.

A number of groups, mainly in France, have studied the effects of potentized dilutions beyond Avogadro's number. While a number of interesting single results have been reported, ${ }^{51,52}$ which have been reviewed in a report soon to be presented to the World Health Organization, ${ }^{53}$ there has been no consistent attempt at isolating one replicable model. ${ }^{18}$

Thus, there are some hints from experimental research that homeopathic substances diluted and succussed beyond Avogadro's number are biologically active but there are no consistent effects from independently reproducible models.

One noticeable advancement has been made: van Wijk and colleagues demonstrated in a series of studies how the similia principle can be captured biologically. ${ }^{\dagger} \pitchfork$ Although these studies were mainly carried out with low doses of substances with some potential molecular action, these investigations are interesting nevertheless because they elucidate what potential avenues the effect can take. Cell cultures were treated with low levels of toxic substances. The cell cultures then expressed different patterns of heat shock or stress proteins, dependent on the substance used, as a sign of the stress the cells suffered. Patterns can be considered as remedy pictures, and chemical compounds can be defined by their degree of similarity regarding these patterns. The following question can then be addressed: Is stimulation of vitality of diseased cells related to the degree of similarity between the symptom pattern of diseased cells and the remedy picture? Cells' survival was recorded for their vitality. Experiments were carried out with a disease induced by physical means: heat shock. These cells were then treated with chemical compounds that were applied in low doses. The chemical compounds were defined by their degree of similarity regarding the heat-shock symptom pattern. Experimental data showed that stimulation of survival capacity was positively correlated with the degree of similarity; the correlation was highly significant. For instance, when heat-shocked cells were treated with low doses of arsenite this resulted in less cell

\footnotetext{
${ }^{\dagger}$ van Wijk R, Wiegant FAC. Cultured Mammalian Cells in Homoeopathy Research: The Similia Principle in Self-Recovery. Utrecht, Germany: Faculteit Biologie, Universiteit Utrecht, 1994.

${ }^{\ddagger}$ van Wijk R, Wiegant FAC. The Similia Principle in Surviving Stress: Mammalian Cells in Homoeopathy Research. Utrecht, Germany: Department of Molecular Cell Biology, Utrecht University, 1997.
} 
death than without treatment. The patterns of arsenite and heat shock show a high degree of similarity. In contrast, a treatment with copper does not decrease cell death; the patterns of heat shock and copper show a low degree of similarity. These data suggest that we can, quite exclusively, rely upon symptomatic (molecular) expression for indicating a treatment. It means that stimulation of the (disease) pattern by another irritation that has a similar pattern is able to extinguish the diseased state in cells and increases the number of surviving cells. ${ }^{54,55}$

Subsequently, research by Jonas and colleagues demonstrated that specific protective proteins and their mRNA precursors are stimulated by specific dilutions of toxins. ${ }^{56}$ This finding bridges the gap somewhat between the simile principle and potential biologic mechanisms but does not address the question of ultra-high dilutions.

Using an in vitro model, Schmidt, Süß, and Nieber evaluated the inhibitory effects of liquid belladonna in high potencies on the acetylcholine-induced contraction of the rat ileum. ${ }^{57}$ This result, of course, also waits for replication.

\section{BASIC RESEARCH}

In order to truly understand the mechanism, one would have to find a plausible theory and experimental backing to clarify how a highly diluted substance can affect a biologic system. Since it is unlikely that a sufficient number of molecules of the initial active agent are present in high dilutions of homeopathic remedies, a researcher would have to explain how a biologic effect can be brought about in the first place. One of the earliest attempts at theoretically explaining potential effects hypothesized that an "imprint" of homeopathic "information" from the molecules dissolved in the remedy is produced by the potentization process, conserved, multiplied by further potentization, and then communicated to the body and taken up as a biologic signal. ${ }^{58-60}$

Different attempts have been made to substantiate the claim that homeopathic dilutions are different from control solutions. A thorough review of existing studies showed that the studies presented so far were methodologically deficient in several respects. ${ }^{61}$ Modern attempts at measuring differences were either negative or produced small effects. However, during the potentization process, ions are dissolved out of the glass vials. Thus, homeopathic potencies always contain many different substances apart from the purported remedial one ${ }^{62,63}$ and, therefore, only studies conducted with succussed controls and in blinded measurements can be informative. Only a few such studies have been performed. A series of studies using nuclear magnetic resonance imaging were able to document differences. ${ }^{64,65}$ However, very thorough predecessor studies, conducted in a triple-blinded setup, were unable to confirm clear-cut and replicable dif- ferences, ${ }^{66}$ and other independent studies yielded sometimes positive,${ }^{67}$ sometimes negative results. ${ }^{68} \mathrm{~A}$ recent study using thermoluminescence found significant differences between a homeopathic test substance and succussed controls, ${ }^{69}$ a result that awaits replication. Another recent study using a high-frequency electromagnetic probing device demonstrated some differences, ${ }^{61}$ while another purported black-box measurement device did not produce replicable results. ${ }^{70}$ A recent thorough attempt to identify a specific set of water clusters in homeopathic preparations that looked promising was subsequently found to be unworkable because the preparations had subtle contaminants. This study clearly showed the complex interdisciplinary expertise required to conduct high-quality research in homeopathy. ${ }^{71} \mathrm{~A}$ review of all extant literature on physical studies trying to identify a materially active component and methodologically rating the studies concluded that most studies were rather weak from a methodological point of view ${ }^{72}$ (see Table 1 for an overview). Together, this very weak literature shows that no viable evidence for stable water clusters (required for so called "water memory") currently exists.

We have developed a model system for testing homoeopathically prepared solutions using the reaction between enzymes and their substrates as the test bed. With this system, we measure the amount of product produced in an enzymesubstrate reaction per unit time in a water environment. We have observed that homeopathically prepared solutions stabilize these reactions in water (manuscript in preparation). Under normal circumstances, enzymes denature in water. However, when in the presence of $\mathrm{C} 30$ potencies of a variety of compounds, this denaturation does not occur. Water diluted and succussed to C30 does not provide a significant level of stabilization. Furthermore, the starting compound influences the degree of enzyme stabilization observed. We have done a careful chemical analysis of the various preparations and have discovered that silica is the principal constituent that varies among the solutions (4-40 micromolar amounts). Succussed water also has dissolved silica in it but at lower concentrations and perhaps in different forms and molecular structures. As silica may occur in a variety of configurations and in various molecular forms with other elements from the glass vials, this could explain the differences among the various solutions. It is reasonable to assume that the nature of the starting material affects the amount and nature of the silica dissolved from the glass. In addition, various forms of silica are known to interact with proteins and have been shown to interact with cells of the immune system. ${ }^{73}$ It is, therefore, possible that this contamination from the walls of the glass in which homeopathic remedies are made is an underlying explanation for some of the effects reported with homeopathic remedies. According to this hypothesis, the mechanism of action is fairly nonspecific and most of the specificity is imparted from the patient's immune system. This could explain the variability observed in a number of published trials and experiments. 
Table 1. Review of Physicochemical Experiments That a Have Been Done to Identify a Therapeutically Active Ingredient in Homeopathic Potencies

\begin{tabular}{lccc}
\hline Method & \# of publications & Years & SAPEH \\
\hline Dielectric strength & 6 & $1951-1983$ & $1-5$ \\
Galvanic effects & 5 & $1971-1992$ & $1-5$ \\
Absorption & 4 & $1941-1995$ & $3-5$ \\
NMR-spectra shape & 8 & $1966-1992$ & $3-6$ \\
NMR-spectra $\mathrm{T}_{1} \mathrm{~T}_{2}$ & 10 & $1985-2001$ & $2-8$ \\
Raman-Spectra & 7 & $1975-1992$ & $2-4$ \\
Black-box devices & 4 & $1993-2000$ & $1-10$ \\
\hline
\end{tabular}

${ }^{\text {a} A c c o r d i n g ~ t o ~ r e f . ~} 72$.

bSAPEH-Score: a quality score that is comprised of Objectives, Controls, Bindings, Randomization, Consistency, Standardization, Statistics, and Presentation of the Results. Maximal SAPEHScore is 10, SAPEH $<6=$ low quality, SAPEH $>7=$ high quality.

NMR, nuclear magnetic resonance.

\section{CLINICAL RESEARCH}

\section{Pathogenetic trials}

Hahnemann's observation that substances ingested by volunteers, even when diluted, produce symptoms was the background for the first blinded experimental study in homeopathy, probably even in the history of pharmacology. It was a trial conducted by homeopaths in Nuremberg in $1835 .{ }^{.4}$ Volunteers were to take either Natrum muriaticum C30 or a control substance from coded bottles and report back after some days. Of the 55 volunteers, 50 produced reports. Eight (8) volunteers had symptoms, 5 with Nat. mur, 3 with water. Thus, this first test ended inconclusively. Homeopaths have conducted many so-called "proving" trials, an inadequate translation of the original German word Prüfung, which means "testing." More recently, these tests have been called pathogenetic trials (PTs). ${ }^{75}$ Normally, provings have not been conducted blindly or in double-blinded fashion and have not been usually evaluated with qualitative methods. The homeopathic epistemology here is circular: Symptoms observed in PTs are being used for treatment. If patients are cured by the remedies prescribed, based on these symptoms, the symptoms are verified, and the remedy picture is supported. If not, the symptom is discarded. Only rarely, and very recently, has this methodology been brought under critical scrutiny and used as an experimental model. Reviews indicate that the vast majority of PTs are largely inadequate from a methodological point of view. ${ }^{76,8}$ However, it should be noted that, for homeopathy to work as a therapeutic system, usual methodological principles, such as blinding or quantitative analysis, are considered to be less relevant because the circular epistemology is said to correct for bias. Modern PTs that serve more of an apologetic and scrutinizing purpose are only partially useful from a homeopathic clinical point of view. They have been conducted with blinding of participants, and differential symptom pictures have been obtained that seem to be useful in therapy. ${ }^{77}$ When subjected to scrutiny in placebo-controlled trials, however, it is difficult to separate symptoms experienced with placebo and symptoms experienced with homeopathic substances. ${ }^{77-80}$ Researchers using more recent study designs have reported that symptoms observed overall are specific and not just "background noise." ${ }^{81-83}$ Very few studies have been done with these recent study designs and much remains to be clarified in this field.

\section{Therapeutic trials}

Naturally, randomized clinical trials have attracted most research interest among researchers and are more wellknown. Several high-quality reviews of all published or a selection of published studies exist (Table 2). ${ }^{84-89}$ There is even a comprehensive review of all clinical studies ever conducted, including early studies published in German. This review concluded that homeopathy is clinically effective. $\|, 90$

In addition, meta-analyses and reviews of several specific diagnoses have been carried out. ${ }^{86,91-98}$ Most of these reviews and meta-analyses, with some exceptions, ${ }^{99-101}$ reached the conclusion that the effects observed in all trials are not compatible with the hypothesis that homeopathy is identical with placebo but that too few trials exist in any single clinical areas to recommend homeopathy clinically. Whether homeopathy is a placebo or not is also dependent on the inclusion and analysis criteria used by a meta-analysis or a review. ${ }^{102-104}$ If the analysis is based on studies re-

\footnotetext{
$\S_{\text {Dantas F, Fisher P, Walach H, et al. Homoeopathic remedy }}$ provings: An international review. 2003; in preparation.

"Dean ME. The Trials of Homeopathy: A Critical-Historical Account of the Origins, Structure and Development of Hahnemann's Scientific Therapeutics, and Two Systematic Reviews of Homeopathic Clinical Trials. York, UK: Department of Health Sciences and Clinical Evaluation, University of York, 2001.
} 
trievable only through MEDLINE ${ }^{\circledR}$ and published in the peer-reviewed literature, the outcome is normally not different from placebo. If all evidence is included, there is a difference from placebo. Hence, the conclusion varies with the decision as to what one is willing to accept as scientific information. ${ }^{105}$ As a result of the bias in the scientific community against homeopathy, it is easier to publish negative results in the peer-reviewed literature than positive ones. The latter are scrutinized more closely for methodological shortcomings than studies with the expected negative outcome, a prominent example being the recently published metaanalysis by Shang and colleagues the reporting of which is unacceptably bad and yet it passed peer-review. ${ }^{104, \mathbb{I}}$ Thus, reviews based on the peer-reviewed literature are likely to underestimate the effect and those outside of this literature are likely to overestimate the effect. Moreover, some evidence has been produced that effect-size between placebo and homeopathy groups decreases, as methodological rigor increases across studies, ${ }^{102,106,107}$ a finding reported in conventional clinical research also.

A summary of studies and conclusions is presented in Tables 2 and 3.

When reviewing the clinical evidence, one should bear in mind that the material is quite heterogeneous. One would, for instance, not ask the question "is conventional medicine a placebo effect?" subjecting all available trials to a metaanalysis. Rather, one would want independent evidence for certain interventions, say statins, to produce a definite outcome, say a decrease in heart-disease-related mortality. In the same vein, one would want a series of relatively similar trials in homeopathy to test for the applicability of homeopathy in certain clinical areas. Only in a few areas has a series of studies been carried out and some of those have been subjected to a meta-analysis (see Table 3). While the meta-analyses are frequently positive overall, these results should be approached with caution. The use of a homeopathic preparation to treat postoperative ileus, for instance, has been shown to be superior to placebo. ${ }^{91}$ However, the largest and most definitive trial in the series yielded negative results. ${ }^{108,109}$ Isopathic preparations for the treatment of atopic conditions with an allergic basis have been shown to be more effective than placebo ${ }^{110-112}$ and a meta-analysis was positive also. ${ }^{98}$ However, a large trial intended to be a replication and a definite study was negative, showing only significant interactions, but no therapeutically beneficial effect, ${ }^{113}$ and other studies in the same area were also inconclusive. ${ }^{114-116}$ Homeopathic therapy has been shown to be useful in childhood diarrhea. A definite study building on a pilot showed clear effects, ${ }^{117,118}$ However, a follow-up study showed effects only for an outcome different from the predefined primary outcome, ${ }^{119}$ and only the meta-analysis found the effect significant. ${ }^{97}$

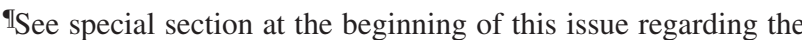
Shang et al. study and the accompanying editorial in The Lancet.
}

A series of studies on homeopathy for chronic headaches/ migraines were built on an initially promising model ${ }^{120,121}$ but were unable to reproduce the effect. ${ }^{122-124}$ The same is true with a seemingly simple and uncontested area: Arnica for muscle soreness after exertion. ${ }^{94,100}$ Only when all $\mathrm{Ar}$ nica studies are put together, independent of the model, can effects be seen..$^{92}$

Our review shows a prominent feature of clinical homeopathy research: The problem is not finding a stunning initial result, as in early studies such as those done with fibromyalgia, ${ }^{125-127}$ or with premenstrual syndrome, ${ }^{128}$ or combination homeopathy in ulcers in children with cancer, ${ }^{129}$ although some recent results from initial studies have produced negative results. ${ }^{131-133}$ The real problem is replicating the effect once it has been seen in a model, potentially in different independent studies. There is, to our knowledge, no single clinical area where reported effects have been demonstrated unequivocally. Thus, the overall picture of clinical evidence that is emerging is quite disappointing for the homeopathic community. Still, the number of studies is quite few compared to research in conventional medicine.

Viewed together, the clinical research on homeopathy compared to placebo is not much different from conventional medicine research where approximately the same proportion of studies are positive and negative. ${ }^{134}$ Once unpublished studies are retrieved from drug-licensing agencies, well-supported substances, such as selective serotonin reuptake inhibitors for depression, show diminishing effects. ${ }^{135,136}$ But overall, effect sizes are still statistically robust, even if diminished. This same result cannot be claimed for homeopathy, except in a few clearly delineated areas (see Table 3).

The situation is different for studies on homeopathic substances compared to active controls or standard treatment. There are considerably fewer studies in this field. ${ }^{137-149}$ But, when taken together, it seems to be much easier to prove equivalence to standard treatments than superiority over placebo. This is certainly a paradox, for standard treatments are supposed to be superior to placebo, and this is the reason they are standard in the first place. Jonas and colleagues did a systematic review (SR) of the homeopathic literature using an established process taken from the behavioral medicine literature that avoided the bias toward drug studies produced by most medical SR approaches. This review allowed for calculation of a "valence effect" (a measure of confidence in reported effects) of homeopathic compared to conventional treatment or placebo comparison groups. The researchers found that homeopathy produced more favorable effects when compared to conventional treatments than compared to placebo studies. Thus, the system of homeopathy may be more beneficial in actual practice than when studying the isolated remedies themselves. ${ }^{150}$

This situation has led to a new movement: the documentation of homeopathic care and its effects in primary or sec- 
Table 2. Comprehensive Systematic Reviews and Meta-Analyses on the General Question of Whether Homeopathy Is Placebo or Not ${ }^{\mathrm{a}}$

\begin{tabular}{|c|c|c|c|c|}
\hline Author (ref.) & $\begin{array}{l}\text { Homeopathy } \\
\text { type/control }\end{array}$ & $\begin{array}{l}N \text { and type } \\
\text { of studies }\end{array}$ & Results & Conclusions \\
\hline Kleijnen et al. $\left({ }^{a}\right)$ & $\begin{array}{l}\text { All/placebo, } \\
\text { conventional }\end{array}$ & 107 CCTs & $\begin{array}{l}81 \text { trials reported } \\
\text { positive results; } \\
\text { most trials low- } \\
\text { quality, but many } \\
\text { exceptions }\end{array}$ & $\begin{array}{l}\text { Available evidence positive } \\
\text { but not sufficient to draw } \\
\text { definitive conclusions }\end{array}$ \\
\hline Linde et al. (87) & All/placebo & 89 RCTs & $\begin{array}{l}\text { OR of all trials over } \\
\text { placebo, } 2.45(95 \% \\
\text { CI, 2.05-2.93); in } \\
\text { better trials, } 1.66 \\
\text { (CI, 1.33-2.08) }\end{array}$ & $\begin{array}{l}\text { Results not compatible with } \\
\text { the hypothesis that all } \\
\text { homeopathy is placebo; } \\
\text { no firm evidence for any } \\
\text { single condition }\end{array}$ \\
\hline Linde and Melchart (88) & $\begin{array}{c}\text { Classical/placebo, } \\
\text { conventional }\end{array}$ & 32 RCTs & $\begin{array}{l}\text { Responder RR vs. } \\
\text { placebo, } 1.62 \text { (CI, } \\
1.17-2.23) ; \text { in } \\
\text { better-quality trials, } \\
1.12 \text { (CI, } 0.87-1.44)\end{array}$ & $\begin{array}{l}\text { Available evidence suggests } \\
\text { effects over placebo; } \\
\text { evidence not convincing } \\
\text { because of shortcomings } \\
\text { and inconsistencies }\end{array}$ \\
\hline Ernst (b) & $\begin{array}{l}\text { Classical/ } \\
\text { conventional }\end{array}$ & $\begin{array}{l}3 \text { RCTs, } 3 \\
\text { CCTs }\end{array}$ & $\begin{array}{l}\text { All trials burdened } \\
\text { with serious } \\
\text { methodological } \\
\text { flaws; results } \\
\text { nonuniform }\end{array}$ & $\begin{array}{l}\text { Relative efficacy of classical } \\
\text { homeopathy compared to } \\
\text { conventional treatments } \\
\text { unknown; no evidence of } \\
\text { effects greater than placebo }\end{array}$ \\
\hline Cucherat et al. (84) & All/placebo & 17 RCTs & $\begin{array}{l}\text { Combined } p \text {-value } \\
\text { for an effect over } \\
\text { placebo }<0.001 ; \\
\text { for best trials only, } \\
p<0.08\end{array}$ & $\begin{array}{l}\text { Some evidence suggests } \\
\text { homeopathy more than } \\
\text { effective placebo; studies } \\
\text { of high quality more } \\
\text { likely to be negative }\end{array}$ \\
\hline Walach $^{\mathrm{c}}$ & $\begin{array}{l}\text { All/placebo } \\
\text { conventional }\end{array}$ & 41 RCTs & $\begin{array}{l}\text { Random-effect size, } \\
0.259 \text { (CI, 0.319- } \\
0.837) \text {; fixed-effects, } \\
0.295 \text { (CI, } 0.223 \text { to } \\
0.366 \text { ) }\end{array}$ & $\begin{array}{l}\text { Effects of homeopathy not } \\
\text { significantly different } \\
\text { from those of placebo }\end{array}$ \\
\hline Shang et al. (104) & $\begin{array}{l}\text { All (unknown)/ } \\
\text { placebo, } \\
\text { conventional }\end{array}$ & $\begin{array}{l}8 \text { RCTs of } \\
110 \\
\text { homeopathic } \\
\text { vs. } 6 \text { RCTs } \\
\text { conventional }\end{array}$ & $\begin{array}{l}\text { OR }=0.88 \text { (CI 0.65- } \\
\text { 1.19) for } \\
\text { homeopathy vs. } \\
\text { placebo (i.e. no } \\
\text { difference); OR = } \\
\text { 0.58 (CI 0.39-0.85) } \\
\text { for conventional } \\
\text { trials (i.e. significant } \\
\text { difference) }\end{array}$ & $\begin{array}{l}\text { Effects of homeopathy } \\
\text { indistinguishable from } \\
\text { placebo, while effects } \\
\text { of conventional trials } \\
\text { remain different from } \\
\text { placebo }\end{array}$ \\
\hline
\end{tabular}

CCT, nonrandomized controlled trial; OR, odds ratio; CI, confidence interval; RCT, randomized controlled trial; RR, rate ratio. Adapted from ref. 86: Jonas WB, Kaptchuk TJ, Linde K. A critical overview of homeopathy. Ann Intern Med 2003;138:393-399, with permission.

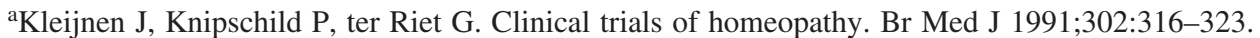

bErnst E. Classical homeopathy versus conventional treatments: A systematic review. Perfusion 1999;12:13-15.

${ }^{c}$ Walach H. The importance of non-specific effects of therapy: The example of homeopathy [in German]. Freiburg, Germany: Philosophische Fakultät, Freiburg, 1997.

ondary care. Most randomized controlled studies start from a rather vague notion of normal practice. Since homeopathy has been used for centuries, it has a special status in some European countries. The remedies are registered, but not tested for efficacy in certain diagnoses. The logic and epistemology of testing is often reversed in traditional healing practices such as homeopathy. ${ }^{151}$ In pharmacology, after a broad basic research and screening process, only few sub- stances make their way to final phase 3 and phase 4 testing for efficacy and, only later, is their broad applicability tested in postmarketing surveillance studies. In homeopathy, there is a well-known and broad spectrum of potential single remedies we know little about in terms of classical efficacy. Thus, testing should start from a broad documentation of safety, satisfaction, and effects, comparable to postmarketing surveillance studies in modern pharmacology. Compar- 
Table 3. Systematic Reviews of Clinical Trials on Homeopathy for Specific Conditions

\begin{tabular}{|c|c|c|c|c|c|}
\hline Author (ref.) & Indication & $\begin{array}{l}\text { Homeopathy typel } \\
\text { control studies }\end{array}$ & $\begin{array}{l}N \text { and } \\
\text { trial types }\end{array}$ & Results & Conclusions \\
\hline $\begin{array}{l}\text { Linde \& } \\
\quad \text { Melchart } \\
(88)\end{array}$ & Asthma & Various/placebo & 3 RCTs & $\begin{array}{l}\text { Trials highly } \\
\text { heterogeneous; } 2 \\
\text { reported statistically } \\
\text { significant effects }\end{array}$ & $\begin{array}{l}\text { Currently available } \\
\text { evidence insufficient } \\
\text { to assess possible } \\
\text { role of homeopathy } \\
\text { for treating asthma }\end{array}$ \\
\hline Ernst (a) & $\begin{array}{l}\text { Headache } \\
\text { prophylaxis }\end{array}$ & $\begin{array}{l}\text { Individualized/ } \\
\text { placebo }\end{array}$ & 4 RCTs & $\begin{array}{l}1 \text { trial positive; } \\
1 \text { partially positive; } \\
2 \text { negative }\end{array}$ & $\begin{array}{l}\text { Trial data do not } \\
\text { suggest effect } \\
\text { over placebo } \\
\text { for prophylaxis } \\
\text { migraine or } \\
\text { headache }\end{array}$ \\
\hline Ernst $\left({ }^{b}\right)$ & $\begin{array}{l}\text { Delayed-onset } \\
\text { muscle } \\
\text { soreness }\end{array}$ & Various/placebo & $\begin{array}{l}8 \text { double- } \\
\text { blinded } \\
\text { trials } \\
\text { (3 explicitly } \\
\text { RCTs) }\end{array}$ & $\begin{array}{l}\text { Most trials had } \\
\text { severe flaws; } \\
\text { the } 3 \text { RCTs } \\
\text { showed no } \\
\text { statistically } \\
\text { significant } \\
\text { effects } \\
\text { over placebo }\end{array}$ & $\begin{array}{l}\text { Published evidence } \\
\text { does not support } \\
\text { hypothesis that } \\
\text { homeopathic } \\
\text { remedies are } \\
\text { effective for } \\
\text { muscle soreness }\end{array}$ \\
\hline $\begin{array}{l}\text { Ernst \& Pittler } \\
\quad(100)\end{array}$ & $\begin{array}{l}\text { All (mainly } \\
\text { trauma }\end{array}$ & $\begin{array}{r}\text { Arnica/placebo, } \\
\text { conventional }\end{array}$ & $\begin{array}{l}4 \text { RCTs; } \\
4 \text { CCTs }\end{array}$ & $\begin{array}{l}2 \text { positive trials; } \\
2 \text { trials with } \\
\text { positive trend; } \\
\text { most studies } \\
\text { had severe } \\
\text { flaws }\end{array}$ & $\begin{array}{l}\text { Claims that } \\
\text { homeopathic Arnica } \\
\text { efficacious not } \\
\text { supported by } \\
\text { rigorous trials }\end{array}$ \\
\hline $\begin{array}{l}\text { Lüdtke \& } \\
\text { Wilkens } \\
(92)\end{array}$ & $\begin{array}{l}\text { All trauma and } \\
\text { postoperatively }\end{array}$ & $\begin{array}{c}\text { Arnica/placebo, } \\
\text { no treatment }\end{array}$ & $\begin{array}{l}23 \text { RCTs; } \\
14 \text { CCTs }\end{array}$ & $\begin{array}{l}\text { Quality often low; } \\
13 \text { of } 35 \text { studies } \\
\text { vs. placebo with } \\
\text { statistically } \\
\text { significant } \\
\text { results, } 10 \text { with } \\
\text { trend toward } \\
\text { significance }\end{array}$ & $\begin{array}{l}\text { Available evidence } \\
\text { suggests that } \\
\text { Arnica } \text { can be } \\
\text { efficacious; } \\
\text { further rigorous } \\
\text { trials needed }\end{array}$ \\
\hline $\begin{array}{l}\text { Vickers \& } \\
\text { Smith }\left(^{(}\right)\end{array}$ & $\begin{array}{l}\text { Influenza-like } \\
\text { syndrome }\end{array}$ & $\begin{array}{l}\text { Oscillococcinum/ } \\
\text { placebo }\end{array}$ & 7 RCTs & $\begin{array}{l}\text { No evidence for } \\
\text { preventive effect } \\
\text { ( } 3 \text { trials) } \\
\text { but reduction of } \\
\text { length of illness } \\
\text { in treatment } \\
\text { trials }\end{array}$ & $\begin{array}{l}\text { Oscillococcinum } \\
\text { probably reduces } \\
\text { duration of influenza- } \\
\text { like syndromes; } \\
\text { further trials } \\
\text { needed }\end{array}$ \\
\hline $\begin{array}{l}\text { Wiesenauer } \\
\text { and } \\
\text { Lüdtke (93) }\end{array}$ & Pollinosis & $\begin{array}{l}\text { Galphimial } \\
\text { placebo }\end{array}$ & $\begin{array}{l}8 \text { RCTs; } \\
1 \text { CS; } \\
2 \text { UCTs }\end{array}$ & $\begin{array}{l}\text { Responder RR } \\
\text { for Galphimia } \\
\text { vs. placebo } \\
\text { from } 7 \text { trials, } \\
1.25(95 \% \\
\text { CI, } 1.09-1.43 \text { ) }\end{array}$ & $\begin{array}{l}\text { Galphima statistically } \\
\text { significantly more } \\
\text { effective than } \\
\text { placebo }\end{array}$ \\
\hline $\begin{array}{l}\text { Barnes et al. } \\
\text { (91) }\end{array}$ & $\begin{array}{l}\text { Postoperative } \\
\text { ileus }\end{array}$ & Various/placebo & $\begin{array}{l}4 \text { RCTs; } \\
2 \text { CCTs }\end{array}$ & $\begin{array}{l}\text { Time to first flatus } \\
\text { in homeopathy } \\
\text { statistically } \\
\text { significantly } \\
\text { shorter; best } \\
\text { trial negative }\end{array}$ & $\begin{array}{l}\text { Available evidence } \\
\text { positive but several } \\
\text { caveats preclude } \\
\text { definitive conclusions }\end{array}$ \\
\hline $\begin{array}{l}\text { Jonas et al. } \\
\text { (86) }\end{array}$ & $\begin{array}{l}\text { Rheumatic } \\
\text { conditions }\end{array}$ & Various/placebo & 6 RCTs & $\begin{array}{l}4 \text { studies achieved } \\
\text { good-quality } \\
\text { scores; combined } \\
\text { OR of these four } \\
\text { studies, 2.11 (CI, } \\
1.32-3.35)\end{array}$ & $\begin{array}{l}\text { Few high-quality placebo- } \\
\text { controlled clinical } \\
\text { trials on treatment } \\
\text { of rheumatic syndromes } \\
\text { with homeopathy and } \\
\text { results are mixed }\end{array}$ \\
\hline
\end{tabular}


Table 3. Systematic Reviews of Clinical Trials on Homeopathy for Specific Conditions (Continued)

\begin{tabular}{|c|c|c|c|c|c|}
\hline Author (ref.) & Indication & $\begin{array}{l}\text { Homeopathy typel } \\
\text { control studies }\end{array}$ & $\begin{array}{l}N \text { and } \\
\text { trial types }\end{array}$ & Results & Conclusions \\
\hline $\begin{array}{l}\text { Taylor et al. } \\
\qquad(98)^{*}\end{array}$ & $\begin{array}{l}\text { Allergic } \\
\text { conditions }\end{array}$ & $\begin{array}{l}\text { Isopathic } \\
\text { nosodes/ } \\
\text { placebo }\end{array}$ & 4 RCTs & $\begin{array}{l}\text { Pooled analysis of } \\
\text { 100-mm visual } \\
\text { analogue scores; } \\
\text { scores were } \\
9.8 \mathrm{~mm}(\mathrm{CI}, \\
4.2-15.4) \text { better } \\
\text { with isopathy }\end{array}$ & $\begin{array}{l}\text { Isopathic nosodes } \\
\text { different from } \\
\text { placebo on both } \\
\text { subjective and } \\
\text { objective measures }\end{array}$ \\
\hline $\begin{array}{l}\text { Jacobs et al. } \\
(95)^{*}\end{array}$ & $\begin{array}{r}\text { Childhood } \\
\text { diarrhea }\end{array}$ & $\begin{array}{l}\text { Classical/ } \\
\text { placebo }\end{array}$ & 3 RCTs & $\begin{array}{l}\text { Combined mean } \\
\text { effect size } \\
\text { differences in } \\
\text { duration of } \\
\text { diarrhea between } \\
\text { groups } 0.66 \text { days } \\
\text { (CI, } 0.16-1.15 ; \\
p=0.008)\end{array}$ & $\begin{array}{l}\text { Individualized homeopathic } \\
\text { treatment decreases the } \\
\text { duration and number of } \\
\text { stools in children with } \\
\text { acute diarrhea, but } \\
\text { sample sizes small }\end{array}$ \\
\hline $\begin{array}{l}\text { Jacobs } \\
\text { et al. }\left({ }^{\mathrm{d}}\right)\end{array}$ & $\begin{array}{r}\text { Rheumatic } \\
\text { diseases }\end{array}$ & $\begin{array}{l}\text { Various/ } \\
\text { placebo }\end{array}$ & 4 CCTs & $\begin{array}{l}\text { Three of four } \\
\text { trials positive; } \\
\text { quality poor }\end{array}$ & $\begin{array}{l}\text { No specific } \\
\text { conclusion on } \\
\text { homeopathy (no } \\
\text { convincing evidence } \\
\text { for alternative } \\
\text { therapies for } \\
\text { rheumatism) }\end{array}$ \\
\hline
\end{tabular}

RCT, nonrandomized, controlled trial; CCT, nonrandomized, controlled trial; CS, cohort study; UCS, uncontrolled study; RR, rate ratio; $\mathrm{CI}$, confidence interval; $\mathrm{OR}$, odds ratio.

* Meta-analytic overviews of researchers of their own trials on the topic.

Adapted from ref. 86: Jonas WB, Kaptchuk TJ, Linde K. A critical overview of homeopathy. Ann Intern Med 2003;138:393-399, with permission.

aErnst E. Homeopathic prophylaxis of headaches and migraine? A systematic review. J Pain Symptom Manage 1999;18:353-357.

${ }^{b}$ Ernst E. Does homeopathic Arnica montana reduce delayed onset muscle soreness? A meta-analysis. Perfusion 1997;11:29-35.

${ }^{\mathrm{c}}$ Vickers AJ, Smith C. Homeopathic Oscillococcinum for preventing and treating influenza and influenza-like syndromes. Cochrane Database Syst 2000; rev. vol.: CD001957.

dJacobs JW, Rasker JJ, Van Riel PL, et al. Alternative treatment methods in rheumatic diseases: A literature review. Ned Tijdschr Geneeskd 1991;135:317-322.

ative effectiveness between two treatments can be tested to find out about pragmatic usefulness compared to standard applications. It is at the end of the epistemological chain that research on mechanisms of action is done. ${ }^{152}$ Thus, the order of testing is reversed. The goal is to document effects in clinical practice broadly. Where such studies are being done, sizeable and stable clinical effects on homeopathy are reported. ${ }^{\#, 153-155}$ Roughly $70 \%$ of all patients using homeopathy report they are considerably improved after treatment, and these effects remain stable during follow-up periods of $2-5$ years.

In summary, there is an efficacy/effectiveness paradox (similar to that found in several other areas of complementary medicine research) with very weak evidence that homeopathy is different from placebo but yet there is documented usefulness in general practice ${ }^{156}$ : We have a therapy that is

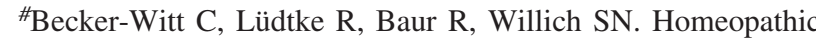
medical practice: Long-term results of a cohort study with 3981 patients. BMC Public Health 2005, submitted. useful when applied in open practice and produces substantial effects, even in patients with chronic diseases. But, according to controlled studies, it is difficult to show that homeopathy is different from placebo.

This leads to the conclusion that, before clinical homeopathy research can proceed with success, it needs a viable theory.

\section{THEORETICAL MODELS}

Hahnemann himself hated speculation. His approach was purely empirical, and he was not given to theorize about the nature of homeopathic effects. We do not have a proper theory of homeopathy from him. He satisfied himself by calling the effect of his remedies "spirit-like," brought about by a "vital force" or a "dynamis" (the Greek term for "power").

This will not do for a modern understanding, since science is built on an intricate interplay between theory and data. Data only make sense in the light of a theory, and theories can only be supported or refuted by data. 
Theories, in the sense of full-fledged models explaining homeopathy from production to therapeutic effects, do not exist. However, there are speculative attempts to explain parts of the puzzle. ${ }^{157,158}$ These attempts can be broadly divided into two classes: local mechanistic models and nonlocal models.

\section{Local models}

Local models start from the assumption that the production process produces some kind of template, image or imprint of the original substance, and that this "information" is the active ingredient. Memory of water is claimed as one potential mechanism. ${ }^{159,160}$ Exactly how this memory should operate is not clear. Several possibilities have been proposed: A selection of water isotopes specific to an originally dissolved substance ${ }^{161}$; an ordering of water molecules to macrostructures, called clathrates, ${ }^{159,162-164}$ that contain the information about substances in the geometry of their ordering; and a selective change in hydrogen bonding, long-range coherence between water molecules that gives potencies laser-like behavior ${ }^{165}$ are a few of the more prominent ideas. Some of these have been theoretically discussed at a high level of specification, some of them remain purely speculative. However, none have been proven. For instance, the lifespan of water macrostructures is in the region of picoseconds, which is far too short to guarantee stability. ${ }^{166}$ Even if these theories could be proven a couple of problems remain: Some remedies are not produced by succussion at all, but by trituration with milk sugar. Would the theories also hold for this special case? Some theories discuss only water. In homeopathy, there is nearly always a variable mix of water and alcohol. Would the chemistry and physics be the same? Hahnemann, in later days, ordered his patients just to sniff medications (i.e., open bottles and smell them) and allow only volatile molecules to make contact. Would those theories also explain this curious situation? If a material information carrier could be demonstrated, precisely how would the organism use this information to produce health again? It has been observed that the data are compatible with a network theory of health, claiming that some "ordering information" is given to the organism that allows it to come out of a state of suboptimal equilibrium, which is the chronically ill state. ${ }^{167,168}$ This model would demand only a minimal energetic impulse or even no impulse at all but just the right information to get the system stimulated. Local models claim that such information is contained in homeopathic remedies.

The combined data of homeopathy research are not compatible with that argument, at least not at the moment. If this were the case, we would expect a similar situation as in conventional pharmacology, namely, that a series of studies succeed in distilling out an effect from such information compared to what happens with controls. What we see in variable models is strong effects in either direction that, when summed up, often cancel each other out. While the deviations from expectation are frequently very strong, defying the argument of random fluctuation, these deviations are rather unsystematic and, up to now, have not been sufficiently stable in any single model to convince critics.

\section{Nonlocal models}

It was this situation that has led some researchers to postulate nonlocal mechanisms, ${ }^{169-179}$ in line with Hahnemann's general way of theorizing. ${ }^{180}$ Several of these models exist and vary in their degree of explicitness and general approach, and also in the way they include the remedy and the practitioner in the equation. Generally speaking, the starting point for these theories is the observation that, in quantum mechanics, so-called nonlocal correlations in welldefined quantum systems are operative. While these decay through interaction with the environment, it might be the case that under similar, isomorphic conditions nonlocal correlations are established in analogy to holistic quantum correlations. A theoretical framework exists that predicts such nonlocal correlations, ${ }^{181}$ and some efforts have been made to apply such a scenario to homeopathy. ${ }^{177}$ While some observations speak in favor of such models, ${ }^{182}$ direct experimental evidence for the existence of nonlocal correlations outside the realm of quantum mechanics is still wanted.

These models have a common consequence: If homeopathic effects are the result of nonlocal correlations, by definition, they cannot be distilled out as causal signals, like in drug therapy. Attempts at strict and direct replication, are doomed to failure. This has to do with a rather technical argument that prohibits the use of nonlocal correlations as direct signals. ${ }^{179}$ (Otherwise, time-reversal paradoxes could be created that contradict special relativity.) As long as the original context is not disturbed and no signal can be distilled out of a setup using such correlations, they could be a very elegant way of coordinating behavior.

The practical consequence of this theory is that clinical research is best conducted by not disturbing the normal clinical practice through experimental interventions such as blinding and randomization and that the placebo-controlled trial is probably a suboptimal method of testing, not only for homeopathy but also for conventional pharmacology. A serious problem with the nonlocal model is that it may not be directly testable in the clinical setting and so cannot be proven as an explanation for homeopathy. Only indirect experimentation is a potential avenue to prove it and this has yet to be established.

\section{CONCLUSIONS}

Our health system has become more effective for treating acute diseases. The downside of it is that chronic diseases have moved into the foreground of health care. Even 
if future medical interventions will be able to solve these problems, it is questionable whether our societies will be able to afford these treatments. ${ }^{183}$ In this situation, homeopathy might be an attractive alternative, since it is a minimal intervention with no known and documented side-effects, capitalizing on the individual organism's capacity to self-heal. Focused conventional intervention, when applied in the complex networks of living organisms, is bound to produce an array of unwanted effects. Thus, the homeopathic strategy may also be helpful for reducing adverse effects from treatment. ${ }^{184,185}$

Homeopathy may thus offer an alternative, if we are willing to set aside the need to know whether its effects are specific. What strategies are the most useful to both study and use homeopathy? We offer a few suggestions about what routes research should and could take in the future:

1. Clinical research is probably most effective if it uses exactly this strength of homeopathy to regulate the system with minimal side-effects and tries to document options and limitations. This could be done in large outcomes studies. These studies should look at homeopathy as it is practiced and provide data on the real-life effects in patients. If well-described cohorts are used, and these cohorts are followed for a long time and compared to conventionally treated ones, this will allow us to estimate the usefulness of homeopathy in practice. Ideally, such an approach would be combined with economic research on costs and feasibility.

2. The next step would be pragmatic comparisons between homeopathy and conventional treatments, which ideally, of course, would be conducted as randomized trials. Since patients seeking homeopathic care often would not like to be randomized, nonrandomized comparisons would also have to be conducted.

3. Placebo-controlled trials are the state of the art in clinical research. Thus, researchers and some authorities will want evidence from such trials. Before conducting such studies, however, it would be advisable to build on extensive pilot data giving an indication of the anticipated effect size, condition, outcome parameters, and length of time of each study.

4. Ideally, the question regarding the nature of homeopathic remedies is directed toward solid laboratory research with plant, in vitro or in vivo models that are controlled, objective, and easily replicable. Since placebo-controlled clinical trials presuppose that there is a causal signal to be isolated in the first place, they may be the wrong method of testing, if the nonlocality hypothesis is correct. Thus, it should be high priority to establish the nature of homeopathic dilutions in fundamental experimental laboratory models. It is mandatory to find a testing system that is broadly accepted and can, in theory, be handled by any competent researcher in the area. If one wants to drill a large hole through a massive wall, it is best to not start drilling a new hole every couple of inches but to stick to one initial groove and carry on drilling. This analogy applies here: One, or at the most, very few different systems should be established and probed, ideally, by independent researchers. If the prediction of a subtle causal information carrier in homeopathic dilutions is borne out, one would expect that a series of wellcontrolled trials should be able to isolate such a signal, even if it is very weak. If the hypothesis of a nonlocal process is true, we would expect no strict replicability, but a deviation toward the predicted and sometimes toward the unpredicted direction, sometimes for the primary, sometimes for the secondary outcomes. Nevertheless, it should be possible to document deviations from chance randomness, if two preconditions are observed:

(a) The testing system must not be too restricted. For instance, deviations should not be forced to be onesided, but should comprise overall deviation statistics, ideally combining an array of parameters, e.g. different parameters of growth.

(b) It is unlikely that the effect will be seen in every test. Thus, a testing model should be chosen that is comparatively low-cost to replicate and a meta-analytic approach should be used to synthesize long series of data.

Thus, experimental testing in simple models would allow us to clarify the nature of homeopathic potencies.

5. In parallel, theory development should proceed. History of science teaches that anomalous data are only incorporated into the corpus of science, once a sound theory is available to understand the data. However, no theory has ever changed the direction of science without good data to support it. Thus, both developments need to go hand-in-hand.

6. The big movement at the moment is toward healing in integrative care, in which different healing modalities have their special places. Homeopathy is not a cure-all. What is needed is to find out in which areas homeopathy works well, or better, than other modalities and to seek cooperation with other modalities for optimal care. For instance, it might be that homeopathy is especially effective for children or for mitigating stress-related diseases. In these cases, it would be worthwhile to establish model clinics in which integrated care is practiced and could be studied as a whole practice against other practices.

7. Only little attention has been paid to patient-practitioner interaction. Part of the secret may be buried here, and intensive qualitative and process-like studies might be able to unveil some of it.

We believe that Hahnemann's discovery is still worthwhile in the twenty-first century. To be recognized as such, 
it is necessary that one legacy of Hahnemann's is strictly discarded, however-his tendency to quarrel and fight with everyone who did not share his opinions. This was his shadow side and it is still haunting homeopathy. And thus homeopaths go on fighting-each other and colleagues of different training and opinions, medical authorities and other doctors, and the health system at large. This is a waste of time and energy, and we suppose that homeopathy would have been easier to integrate had it not been for this tendency. It is time to drop this and to adopt a more mature stance that is aware both of the strengths and the weaknesses of homeopathy, and that is willing to look openly at both and to learn continually from experience. The latter is a theme, common both to science and homeopathy.

\section{ACKNOWLEDGMENTS}

The authors thank Cindy Crawford, B.A., for valuable help in the background.

\section{REFERENCES}

1. Schmidt JM. The Publications of Samuel Hahnemann [in German]. Sudhoffs Archiv 1988;72:14-36.

2. Schmidt JM. History and relevance of the 6th edition of The Organon of Medicine (1842). Br Homoeopathic J 1994;83: $42-48$.

3. Hahnemann S. Lesser Medical Writings [in German; University of Nachdruck edition]. Heidelberg: Haug, 1971 [original published by Dresden: Arnold, 1929].

4. Hahnemann S. Organon of Healing, vol. 6. Stuttgart: Hippokrates, 1979.

5. Hahnemann S. Organon of Medicine. Los Angeles: JP Tarcher, 1982.

6. Vonessen F. What Creates Disease Will Also Heal: Mythical Thinking in Identities, Aristotle's Teaching of Catharsis and the Idea of Homeopathic Healing [in German]. Heidelberg: Haug, 1980.

7. Walach H. Homeopathy as Basic Therapy: Towards a Scientific Foundation of Homeopathy [in German]. Heidelberg: Haug; 1986.

8. Schadewaldt H. The similarity principle in Paracelsus [first of 2 papers; in German]. Allgemeine Homöopathische Zeitung 1972;217:265-268.

9. Schadewaldt H. The similarity principle in Paracelsus [second of 2 papers; in German]. Allgemeine Homöopathische Zeitung 1973;218:12-20.

10. Jütte R. 200 years of [the] similarity principle: Magic, medicine, metaphor. Allgemeine Homöopathische Zeitung 1997; 242:3-16.

11. Haller AV. Pharmacopoea Helvetica [Swiss Pharmacopoeia [in Latin]. Basel: Im Hof, 1771.

12. Teixeira MZ. Similitude in modern pharmacology. $\mathrm{Br} J$ Homeopathic 1999;88:112-120.

13. Eskinazi D. Homeopathy re-revisited: Is homeopathy compatible with biomedical observations? Arch Int Med 1999;159:1981-1987.

14. Walach H, Jonas WB. Homeopathy. In: Lewith G, Jonas WB,
Walach H, eds. Clinical Research in Complementary Therapies: Principles, Problems, and Solutions. London: Churchill Livingstone, 2002:229-246.

15. Kaptchuk TJ. Intentional ignorance: A history of blind assessment and placebo controls in medicine. Bull History Med 1998;72:389-433.

16. Kolisko L. Physiological and Physical Evidence of the Efficacy of Smallest Entities. Stuttgart: Verlag "Der kommende Tag," 1923.

17. Kollerstrom J. Basic scientific research into the "low-dose effect." Br Homoeopathic J 1982;71:414-447.

18. Vickers A. Independent replication of pre-clinical research in homoeopathy: A systematic review. Forschende Komplementärmedizin 1999;6:311-320.

19. Pongratz W, Nograsek A, Endler CP. Highly diluted agitated silver nitrate and wheat seedling development - effect kinetics of a process of successive agitation phases. In: TaddeiFerretti C, Marotta P, eds. High Dilution Effects on Cells and Integrated Systems. London: World Scientific Publishers, 1997.

20. Linde K, Jonas WB, Melchart D, et al. Critical review and meta-analysis of serial agitated dilutions in experimental toxicology. Human and Experimental Toxicology 1994;13: 481-492.

21. Szeto AL, Rollwagen F, Jonas WB. Rapid induction of protective tolerance to potential terrorist agents: A systematic review of low- and ultra-low dose research. Homeopathy 2004;93:173-178.

22. Albrecht H, van Wijk R, Dittloff S. A new database on basic research in homeopathy. Homeopathy 2002;91:162-165.

23. Poitevin B, M. A, Benveniste J. An approach to a quantitative analysis of the effect of Apis mellifica on the in vitro degranulation of basophils in humans [in French]. Innovation et Technologie en Biologie et Médecine 1986;7:64-68.

24. Poitevin B, Davenas E, Benveniste J. In vitro immunological degranulation of human basophils is modulated by lung histamine and Apis mellifica. Br J Clin Pharmacol 1988;25: 439-444.

25. Sainte-Laudy J, Belon P, Cherruault Y. Pharmacological study of Hahnemannian dilutions of human basophil degranulation [in French]. In: Boiron J, Belon P, Hariveau E, eds. Research in Homeopathy. Sainte-Foy-les-Lyon, France: Fondation Francaise pour la Recherche en Homeopathie, 1986:41-58.

26. Sainte-Laudy J, Haynes D, Gershwin G. Inhibition effects of whole blood dilutions on basophil degranulation. Int J Immunother 1986;2:247-250.

27. Davenas E, Beauvais F, Amara J, Benveniste J. Human basophil degranulation triggered by very dilute antiserum against IgE. Nature 1988;333:816-818.

28. Hirst SJ, Hayes NA, Burridge J, et al. Human basophil degranulation is not triggered by very dilute antiserum against human IgE. Nature 1993;366:525-527.

29. Ovelgönne JH, Bol A, Hop WCJ, van Wijk R. Mechanical agitation of very dilute antiserum against $\operatorname{IgE}$ has no effect on basophil staining properties. Experientia 1992;48:504508.

30. Benveniste J, Davenas E, Ducot B, et al. Succussion of high dilutions does not induce specific biological activity [in French]. Comptes Rendus de l'Academie des Sciences Paris 1991;312:461-466. 
31. Schiff M. The Memory of Water: Homoeopathy and the Battle of Ideas in the New Science. London: HarperCollins, 1995.

32. Benveniste J. From water memory to digital biology. Network 1999;69:11-14.

33. Hadji L, Arnoux B, Benveniste J. Effect of dilute histamine on coronary flow of guinea-pig isolated heart. FASEB J 1991;5A:1583.

34. Ives J. Evaluating unusual claims and devices using a team approach: A case study. Subtle Energies Energy Med 2002; 13:39-59.

35. Belon P, Cumps J, Ennis M, et al. Histamine diluations modulate basophil activation. Inflamm Res 2004;53:181-188.

36. Lorenz I, Schneider EM, Stolz P, et al. Influence of the diluent on the effect of highly diluted histamine on basophil activation. Homeopathy 2003;92:11-18.

37. Lorenz I, Schneider EM, Stolz P, et al. Sensitive flox cytometric method to test basophil activation influenced by homeopathic histamine dilution. Forschende Komplementärmedizin und Klassische Naturheilkunde 2003;10:316-324.

38. Guggisberg AG, Baumgartner SM, Tschopp CM, Heusser P. Replication study concerning the effects of homeopathic dilutions of histamine on human basophil degranulation in vitro. Complement Ther Med 2005;13:91-100.

39. Baumgartner S, Guggisberg AG. Degranulation of basophils, third scene: Homeopathy and basophil degranulation-less clear than some would have thought [in German]. Forschende Komplementärmedizin und Klassische Naturheilkunde 2005;12:52-54.

40. Dittmann J, Kanapin H, Harisch G. Biochemische Biochemical effects of homeoopathic and electronic potencies of $8 \mathrm{X}$ of Kalium cyanite [in German]. Forschende Komplementärmedizin 1999;6:15-18.

41. Dittmann J, Harisch G. Characterization of differing effects caused by homoeopathically prepared and conventional dilutions using cytochrome P450 2E1 and other enzymes as detection systems. J Altern Complement Med 1996;2:279290.

42. Harisch G, Kretschmer M. Histamine release from rat peritoneal mast cells after oral doses of homoeopathically prepared minerals and disodium cromoglycate. J Appl Nutr 1989;41:45-49.

43. Harisch G, Kretschmer M. Smallest zinc quantities affect the histamine release from peritoneal mast cells of the rat. Experientia 1988;44:761-762.

44. Then C, Dittmann J, Schütte A, et al. In vitro studies of the effect of Arsenicum album potencies in cell cultures using a MTT test [in German]. Forschende Komplementärmedizin 1996;3:222-228.

45. Endler PC, Pongratz W, van Wijk R, et al. Effects of highly diluted succussed thyroxine on metamorphosis of highland frogs. Berlin J Res Homoeopathy 1991;1:151-160.

46. Endler PC, Pongratz W, Smith CW, Schulte J. Non-molecular information transfer from thyroxine to frogs with regard to homeopathic toxicology. Vet Hum Toxicol 1995;37: 259-260.

47. Endler PC, Pongratz W, Kastberger. The effect of highly diluted agitated thyroxine on the climbing activity of frogs. Vet Hum Toxicol 1994;36:56-59.

48. Zausner C, Lassnig H, Endler CP, et al. Effects of homeopathically prepared thyroxin on meta-morphosis of highland frogs—results of a multicenter controlled study [in German]. Perfusion 2002;15:268-276.

49. Alex J, Dieterle D, Lüdtke R, et al. The effects of homeopathically potentised thyroxin on speed of metamorphosis of the grass frog (Rana temporaria) [in German]. In: Albrecht $\mathrm{H}$, Frühwald $\mathrm{M}$, eds. Yearbook of Carl und Veronica Carstens-Stiftung, vol. 5. Essen: KVC Verlag; 1999:197-210.

50. Guedes JRP, Ferreira CM, GuimarÆes HMB, et al. Homeopathically prepared dilution of Rana catesbeiana thyroid glands modifies its rate of metamorphosis. Homeopathy 2004;93:132-137.

51. Kuzeff RM, Topashka-Ancheva MN, Mecheva RP. Inhibition of (-)-propranolol hydrochloride by its enantiomer in white mice. Forschende Komplementärmedizin und Klassische Naturheilkunde 2003;10:309-314.

52. Kuzeff RM, Mecheva RP, Topashka-Ancheva MN. Inhibition of (-)-propranolol hydrochloride by its enantiomer in white mice-a placebo-controlled randomized study. Forschende Komplementärmedizin und Klassische Naturheilkunde 2004;11:14-19.

53. van Wassenhoven M. Priorities and methods for developing the evidence profile of homeopathy: Recommendations of the ECH General Assembly and XVIII Symposium of GIRI. Homeopathy 2005;94:107-124.

54. Wiegant FAC, Souren JEM, van Rijn J, van Wijk R. Stressor specific induction of heat shock protein in rat hepatoma cells. Toxicology 1994;94:143-159.

55. Wiegant FAC, Souren JEM, van Wijk R. Stimulation of survival capacity in heat treated cells by subsequent exposure to minute amounts of chemical stressors: Role of similarity in stressor effect. In: Collery H, Bratter P, Negretti de Bratter $\mathrm{V}$, et al, eds. Metal Ions in Biology and Medicine vol 5. Paris: J. Libbey Eurotext, 1998:146-150.

56. Gaddipati JP, Rajeshkumar NV, Grove JC, et al. Low dose cadmium exposure reduces human prostate cell transformation in culture and up-regulates methallothionein and MT-1G mRNA. Nonlinearity Biol Toxicol Med 2003;1:199-212.

57. Schmidt F, Süß WG, Nieber K. In vitro testing of homeopathic dilutions [in German]. Biologische Medizin 2004; 33:32-37.

58. Barnard GP, Stephenson JH. Microdose paradox: A new biophysical concept. J Am Inst Homeopathy 1967;60:277-286.

59. Stephenson J. On possible field effects of the solvent phase of sucussed high dilutions. J Am Inst Homeopathy 1966;59:259-262.

60. Stephenson J. Review of investigations into the actions of substances in dilutions greater than $1 \times 10(-24)$ (microdilutions). Br Homoeopathic J 1973;62:3-18.

61. Witt C. Using Methods of Physics to Study Homeopathic High Potencies [in German]. Essen: KVC Verlag, 2000.

62. Zacharias CR. Contaminants in commercial homoeopathic medicines. Br Homoeopathic J 1995;84:71-74.

63. Zacharias CR. Implications of contaminants to scientific research in homoeopathy. Br Homoeopathic J 1995;84:3-5.

64. Demangeat JL, Gries P, Poitevin B, et al. Low-field NMR water proton longitudinal relaxation in ultrahigh diluted aqueous solutions of silica-lactose prepared in glass material for pharmaceutical use. Appl Magnetic Resonance 2004;26:465-481.

65. Demangeat JL, Demangeat D, Gries P, et al. Modification of relaxation times of protons in nuclear magnetic resonance spectroscopy at $4 \mathrm{MHz}$ of a very high dilution of silica ni- 
trate or lactose [in French] J de Medecine Nucleaire et Biophysique 1992;16:135-145.

66. Weingärtner O. Homeopathic potencies [in German]. Wunsch und Wirklichkeit bei der Suche nach der therapeutisch wirksamen Komponente. Berlin \& Heidelberg: Springer, 1992.

67. Jonas WB, Dillner DK. Protection of mice from tularemia infection with ultra-low, serial agitated dilutions prepared from Francisella tularensis-infected tissue. J Sci Explo 2000;14: 35-52.

68. Aabel S, Fossheim S, Rise F. Nuclear magnetic resonance (NMR) studies of homeopathic solutions. Br Homeopathic J 2001;90:14-20.

69. Rey L. Thermoluminescence of ultra-high dilutions of lithium chloride and sodium chloride. Physica A 2003;323:67-74.

70. Walach H, van Asseldonk T, Bourkas P, et al. Electric measurement of ultra-high dilutions - a blinded controlled experiment. Br Homoeopathic J 1998;87:3-12.

71. Anick DJ. High sensitivity 1 H-NMR spectroscopy of homeopathic remedies made in water. BMC Complement Altern Med 2004;4:15.

72. Becker-Witt C, Weißhuhn TER, Lüdtke R, Willich SN. Quality assessment of physical research in homeopathy. J Altern Complement Med 2003;9:113-132.

73. Xynos ID, Edgar AJ, Buttery LDK, et al. Ionic products of bioactive glass dissolution increase proliferation of human osteoblasts and induce insulin-like growth factor II mRNA expression and protein synthesis. Biochem Biophys Res Communications 2000;276:461-465.

74. Stolberg M. Homeopathy on trial: The first double blind experiment of medical history in the year 1835 [in German]. Münchner Medizinische Wochenschrift 1996;138:364-366.

75. Dantas F. How can we get more reliable information from homoepathic pathogenetic trials? A critique of provings. $\mathrm{Br}$ Homoeopathic J 1996;85:230-236.

76. Dantas F, Fisher P. A systematic review of homoeopathic pathogenetic trials ("provings") published in the United Kingdom from 1945 to 1995 . In: Ernst E, Hahn EG, eds. Homoeopathy: A Critical Appraisal. London: ButterworthHeineman, 1998:69-97.

77. Riley DS. Contemporary drug provings. J Am Inst Homeopathy 1994;87:161-165.

78. Walach H, Hieber S, Ernst-Hieber E. Effects of Belladonna $12 \mathrm{CH}$ and $30 \mathrm{CH}$ in healthy volunteers: A multiple, singlecase experiment in randomization design. In: Bastide M, ed. Signs and Images: Selected Papers from the 7th and 8th GIRI Meeting [Montpellier, France, November 20-21, 1993, and Jersualem, Israel, December 10-11, 1994]. Dordrecht, Boston \& London: Kluwer, 1997:215-226.

79. Walach H. Does a highly diluted homoeopathic drug act as a placebo in healthy volunteers? Experimental study of Belladonna C30. J Psychosomatic Res 1993;37:851-860.

80. Walach H, Köster H, Hennig T, Haag G. The effects of homeopathic Belladonna $30 \mathrm{CH}$ in healthy volunteers-a randomized, double-blind experiment. J Psychosomatic Res 2001;50:155-160.

81. Walach H, Sherr J, Schneider R. Homeopathic proving symptoms: Result of a local, non-local, or placebo process? A blinded, placebo-controlled pilot study. Homeopathy 2004;93:179-185.
82. Möllinger H, Schneider R, Löffel M, Walach H. A doubleblind, randomized, homeopathic pathogenetic trial with healthy persons: Comparing two high potencies. Forschende Komplementärmedizin und Klassische Naturheilkunde 2004;11:274-280.

83. Walach H, Kohls N. Grade-of-Membership (GoM) - analysis as a sensitive method for evaluating categorical data-introduction and some examples. In: Beauducel A, Biehl B, Bosniak M, eds. Multivariate Research Strategies-Festschrift for Werner W Wittmann. Aachen: Shaker, 2005:151-172.

84. Cucherat M, Haugh MC, Gooch M, et al. Evidence of clinical efficacy of homeopathy: A meta-analysis of clinical trials. Eur J Clin Pharmacol 2000;56:27-33.

85. Jonas WB, Kaptchuk TJ, Linde K. A critical overview of homeopathy. Ann Intern Med 2003;138:393-399.

86. Jonas WB, Linde K. Homeopathy and rheumatic disease. Rheum Dis Clin North Am 2000;26:117-123.

87. Linde K, Clausius N, Ramirez G, et al. Are the clinical effects of homoeopathy placebo effects? A meta-analysis of placebo controlled trials. Lancet 1997;350:834-843.

88. Linde K, Melchart D. Randomized controlled trials of individualized homeopathy: A state-of-the-art review. J Altern Complement Med 1998;4:371-388.

89. Linde K, Hondras M, Vickers A, ter Riet G, Melchart D. Systematic reviews of complementary therapies - an annotated bibliography: Part 3. Homeopathy. BMC Complement Altern Med 2001;1(4).

90. Dean ME. The Trials of Homeopathy: Origins, Structure, and Development. Hans Walz Preisschrift. Essen: KVC Verlag, 2004.

91. Barnes J, Resch KL, Ernst E. Homeopathy for postoperative ileus? A meta-analysis. J Clin Gastroenterol 1997;25:628633.

92. Lüdtke R, Wilkens J. Studies on clinical efficacy of arnica in homeopathic preparations [in German]. In: Yearbook of Carl and Veronica Carstens-Stiftung, vol. 5. Edited by Albrecht H, Frühwald M, eds. Essen: KVC Verlag, 1999; 97-112.

93. Wiesenauer M, Lüdtke R: A meta-analysis of the homoeopathic treatment of pollinosis with Galphimia glauca. Forschende Komplementärmedizin 1996;3:230-234.

94. Ernst E, Barnes J. Are homoeopathic remedies effective for delayed-onset muscle soreness? A systematic review of placebo-controlled trials. Perfusion 1998;11:4-8.

95. Jacobs J, Jonas WB, Jiménez-Pérez M, Crothers D. Homeopathy for childhood diarrhea: Combined results and metaanalysis from three randomized, controlled clinical trials. Ped Infect Dis J 2003;22:229-234.

96. Mathie R. The research evidence base for homeopathy: A fresh assessment of the literature. Homeopathy 2003;92: 84-91.

97. Walach H. Homeopathy in children-results of clinical studies [in German]. Kinder- und Jugendarzt 2002;33:950954.

98. Taylor MA, Reilly D, Llewellyn-Jones RH, et al. Randomised controlled trial of homoeopathy versus placebo in perennial allergic rhinitis with overview of four trial series. Br Med J 2000;321:471-476.

99. Ernst E. Are highly dilute homoeopathic remedies placebos? Perfusion 1998;11:291-292. 
100. Ernst E, Pittler MH. Efficacy of homeopathic Arnica: A systematic review of placebo-controlled clinical trials. Arch Surg 1998;133:1187-1190.

101. Vickers AJ, Fisher P, Smith C, et al. Homoeopathic Arnica $30 \mathrm{X}$ is ineffective for muscle soreness after long distance running: A randomized, double-blind, placebo-controlled trial. Clin J Pain 1998;14:227-231.

102. Linde K, Scholz M, Ramirez G, et al. Impact of study quality on outcome in placebo-controlled trials of homeopathy. J Clin Epidemiol 1999;52:631-636.

103. Linde K, Willich SN. How objective are systematic reviews? Differences between reviews on complementary medicine. J Royal Soc Med 2003;96:17-22.

104. Shang A, Huwiler-Münteler K, Nartey L, et al. Are the clinical effects of homeopathy placebo effects? Comparative study of placebo-controlled trials of homoeopathy and allopathy. Lancet 2005;366:726-732.

105. Pittler MH, Abbot NC, Harkness EF, Ernst E. Location bias in controlled clinical trials of complementary/alternative therapies. J Clin Epidemiol 2000;53:485-489.

106. Ernst E, Pittler MH: Re-analysis of previous meta-analyis of clinical trials of homeopathy. J Clin Epidemiol 2000;53:1188.

107. Lüdtke R. Statistical comments on a re-analysis of a previous meta-analysis of homeopathic RCTs. J Clin Epidemiol 2002;55:102-104.

108. Mayaux MJ, Guihard-Moscato ML, Schwartz D, Benveniste J. Controlled clinical trial of homoeopathy in postoperative ileus [letter]. Lancet 1988, 5:528-529.

109. Groupe de Recherche et d Essais Cliniques en Homéopathie. Evaluation of two homeopathic products on the transit of bowel after abdominal surgery: A controlled multi-center study [in French]. Presse Médicale 1989;18:59-62.

110. Reilly D, Taylor MA, Beattie NGM, et al. Is evidence for homoeopathy reproducible? Lancet 1994;344:1601-1606.

111. Reilly DT, Taylor MA. Potent placebo or potency? A proposed study model with initial findings using homeopathically prepared pollens in hayfever. $\mathrm{Br}$ Homoeopathic $\mathrm{J}$ 1985;74:65-75.

112. Reilly DT, Taylor MA, Mc Sharry C, Aitchinson T. Is homoeopathy a placebo response? Controlled trial of homoeopathic potency with pollen in hayfever as a model. Lancet 1986;18:881-886.

113. Lewith GT, Watkins AD, Hyland ME, et al. Use of ultramolecular potencies of allergen to treat asthmatic people allergic to house dust mite: Double blind randomised controlled clinical trial. Br Med J 2002, 324:520-523.

114. Aabel S, Laerum E, Dolvik S, Djupesland P. Is homeopathic "immunotherapy" effective? A double-blind, placebo-controlled trial with the isopathic remedy Betula 30c for patients with birch pollen allergy. Br Homeopathic J 2000;89: 161-168.

115. Aabel S. No beneficial effect of isopathic prophylactic treatment for birch pollen allergy during a low pollen season: A double-blind, placebo controlled clinical trial of homeopathic Betula 30c. B Homeopathic J 2000;89:169-173.

116. Aabel S. Prophylactic and acute treatment with the homeopathic medicine Betula 30c for birch pollen allergy: A double-blind, randomized, placebo-controlled study of consistency of VAS responses. Br Homeopathic J 2001;90: 73-78.
117. Jacobs J, Jiminez LM, Gloyd S, et al. Homoeopathic treatment of acute childhood diarrhoea. Br Homoeopathic J 1993;82:83-86.

118. Jacobs J, Jimenez LM, Gloyd SS, et al. Treatment of acute childhood diarrhea with homeopathic medicine: A randomized clinical trial in Nicaragua. Pediatrics 1994;93:719-725.

119. Jacobs J, Jimenez LM, Malthouse S, et al. Homeopathic treatment of acute childhood diarrhea: Results from a clinical trial in Nepal. J Altern Complement Med 2000;6:131-139.

120. Brigo B, Serpelloni G. Homoeopathic treatment of migraines: A randomized double-blind controlled study of sixty cases (homoeopathic remedy versus placebo). Berlin J Res Homoeopathy 1991;1:98-106.

121. Brigo B, Serpelloni G. Homeopathic treatment of migraine: A controlled, double-blind study of 60 cases of homoeopathic remedy versus placebo [in French]. J Liga Medicorum Homoeopatica Internationalis 1987;1:18-25.

122. Whitmarsh TE, Coleston-Shields DM, Steiner TJ. Doubleblind randomized placebo-controlled study of homoeopathic prophylaxis of migraine. Cephalalgia 1997;17:600-604.

123. Walach H, Gaus W, Haeusler W, et al. Classical homoeopathic treatment of chronic headaches: A double-blind, randomized, placebo-controlled study. Cephalalgia 1997;17:119-126.

124. Straumsheim P, Borchgrevink C, Mowinkel P, et al. Homoepathic treatment of migraine: A double blind, placebo controlled trial of 68 patients. Br Homeopathic J 2000;89:4-7.

125. Bell IR, Lewis II DA, Schwartz GE, Lewis SA, et al. Electroencephalographic cordance patterns distinguish exceptional clinical responders with fibromyalgia to individualized homeopathic medicines. J Altern Complement Med 2004; 10:285-299.

126. Bell IR, Lewis II DA, Brooks A, et al. Improved clinical status in fibromyalgia patients treated with individualized homoepathic remedies versus placebo. Rheumatology 2004;43: 577-582.

127. Bell IR, Lewis II DA, Brooks AJ, et al. Individual differences in response to randomly assigned active individualized homeopathic and placebo treatment in fibromylagia: Implications of a double-blinded optional crossover design. J Altern Complem Med 2004;10:269-283.

128. Yakir M, Kreitler S, Brzezinski A, et al. Effects of homeopathic treatment in women with premenstrual syndrome: A pilot study. Br Homeopathic J 2001;90:48-153.

129. Oberbaum M, Yaniv I, Ben-Gal Y, et al. A randomized, controlled clinical trial of the homeopathic medication TRAUMEEL $S$ in the treatment of chemotherapy-induced stomatitis in children undergoing stem cell transplantation. Cancer 2001;92:684-690.

130. Jacobs J, Springer DA, Crothers D. Homeopathic treatment of acute otitis media in children: A preliminary randomized placebo-controlled trial. Ped Infect Dis J 2001;20:177-183.

131. Jacobs J, Herman P, Heron K, Olsen S, Vaughters L. Homeopathy for menopausal symptoms in breast cancer survivors: A preliminary randomized controlled trial. J Altern Complement Med 2005;11:21-27.

132. Thompson EA, Montgomery A, Douglas D, Reilly D. A pilot, randomized, double-blinded, placebo-controlled trial of individualized homeopathy for symptoms of estrogen withdrawal in breast-cancer survivors. J Altern Complement Med 2005;11:13-20. 
133. Weatherly-Jones E, Nicholl JP, Thomas KJ, et al. A randomised, controlled, triple-blind trial of the efficacy of homeopathic treatment for chronic fatigue syndrome. J Psychosomatic Res 2004;56:189-197.

134. Albrecht H. Clinical research in homeopathy-a critical evaluation [in German]. Allgemeine Homöopathische Zeitung 1999;244:47-55.

135. Kirsch I, Moore TJ, Scoboria A, Nicholls SS. The emperor's new drugs: An analysis of antidepressant medication data submitted to the U.S. Food and Drug Administration. Prevention \& Treatment Online document at: http://journalsapaorg/prevention 2002;5:Article 23.

136. Khan A, Khan S, Brown WA. Are placebo controls necessary to test new antidepressants and anxiolytics? Int J Neuropsychopharmacol 2002;5:193-197.

137. Friese K-H, Kruse S, Lüdtke R, Moeller H. The homoeopathic treatment of otitis media in children: Comparisons with conventional therapy. Int J Clin Pharmacol Ther 1997; 35:296-301.

138. Gibson RG, Gibson SLM, MacNeill AD, Buchanan WW. The place for non-pharmaceutical therapy in chronic rheumatoid arthritis: A critical study of homoeopathy. Br Homoeopathic J 1980;69:121-133.

139. Gmünder R, Kissling R. The effects of classical homeopathy in comparison to standardised physiotherapy in the treatment of chronic low back pain [in German]. Zeitschrift für Orthopädie 2002;140:503-508.

140. Harrison H, Fixsen A, Vickers A. A randomized comparison of homoeopathic and standard care for the treatment of glue ear in children. Complement Ther Med 1999;7:132-135.

141. Issing W, Klein $\mathrm{P}$, Weiser M. The homeopathic preparation Vertigoheel versus Ginkgo biloba in the treatment of vertigo in an elderly population: A double-blinded, randomized, controlled clinical trial. J Altern Complement Med 2005; 11:155-160.

142. Nahler G, Metelmann H, Sperber H. Treatment of arthritis of the knee with Zeel comp.-results of a randomised controlled clinical trial in comparison to hyaluric acid [in German]. Orthopädische Praxis 1996;32:354-359.

143. Nusche M. Homeopathy or penicillin in throat infections? A prospective clinical study [in German]. Stuttgart: Hippokrates, 1998.

144. Riley D, Fischer M, Singh B, et al. Homeopathy and conventional medicine: An outcomes study comparing effectiveness in a primary care setting. J Altern Complem Med 2001;7:149-159.

145. Stam C, Bonnet MS, Van Haselen RA. The efficacy and safety of a homeopathic gel in the treatment of acute low back pain: A multicentre, randomised, double-blind comparative clinical trial. Br Homeopathic J 2001;90:21-28.

146. Stippig SG. Upper respiratory tract infections in children: Homeopathic and conventional treatment are equally good [in German]. Der Allgemeinarzt 1996;18:931-936.

147. Van Haselen RA, Fisher PAG. A randomized controlled trial comparing topical piroxicam gel with a homeopathic gel in osteoarthritis of the knee. Rheumatology 2000;39:714-719.

148. Weiser M, Gegenheimer LH, Klein P. A randomized equivalence trial comparing the efficacy and safety of Luffa comp.HEEL nasal spray with cromoly sodium spray in the treatment of seasonal allergic rhinitis. Forschende Komplementärmedizin 1999;6:142-148.
149. Weiser M, Strösser W, Klein P. Homeopathic vs. conventional treatment of vertigo: A randomized double-blind controlled clinical study. Arch Otolaryngol-Head Neck Surg 1998;124:879-885.

150. Jonas WB, Anderson RL, Crawford CC, Lyons JS. A systematic review of the quality of homeopathic clinical trials. BMC Complementary and Alternative Medicine 2001,1(12): Online document at: www.pubmedcentral.nih.gov/picrender.fcgi artid $=64638 \&$ blobtype $=$ pdf Accessed October 10, 2005.

151. Verhoef MJ, Lewith G, Ritenbaugh C, et al. Whole systems research: Moving forward. Focus Altern Complement Ther 2004;9:87-90.

152. Jonas WB. The evidence house. Forschende Komplementärmedizin und Klassische Naturheilkunde 2005;12:159-157.

153. Güthlin $\mathrm{C}$, Lange $\mathrm{O}$, Walach $\mathrm{H}$. Measuring the effects of acupuncture and homoeopathy in general practice: An uncontrolled prospective documentation approach. BMC Public Health 2004;4:6.

154. Becker-Witt C, Lüdtke R, Weisshuhn TER, Willich SN. Diagnoses and treatment in homeopathic medical practice. Forschende Komplementärmedizin und Klassische Naturheilkunde 2004;11:98-103.

155. Becker-Witt C, Keil T, Roll S, Menke D, et al. Effectiveness and costs of homeopathy compared to conventional medicine-a prospecitve multicenter cohort study. In: 2003-2003: Improving the Success of Homeopathy, vol. 4. London: Faculty of Homeopathy, 2003.

156. Walach $\mathrm{H}$. The efficacy paradox in complementary medicine [in German]. Forschende Komplementärmedizin und Klassische Naturheilkunde 2001;8:193-195.

157. Schulte J. Effects of potentization in aqueous solutions. $\mathrm{Br}$ Homeopathic J 1999;88:155-160.

158. Poitevin B. Mechanism of action of homoeopathic medicines: Recent findings and hypotheses 1 . Physicochemical mechanisms. Br Homoeopathic J 1995;84:32-39.

159. Endler PC. Water and Information [in German]. Heidelberg: Haug im Druck, 1996.

160. Kratky KW. Homeopathy and water structure: A physical model [in German]. Forschende Komplementärmedizin und Klassische Naturheilkunde 2004;11:24-32.

161. Berezin AA. Isotopical positional correlations as a possible model for Benveniste experiments. Med Hypotheses 1990; 31:43-45.

162. Anagnostatos GS. Small water clusters (clathrates) in the homoeopathic preparation process. In: Endler PC, Schulte J, eds. Ultra High Dilution-Physiology and Physics. Dordrecht: Kluwer, 1994:121-128.

163. Matsumoto J. Molecular mechanism of biological responses to homoeopathic medicines. Med Hypotheses 1995;45:292-296.

164. Torres JL. On the physical basis of succussion. Homeopathy 2002;91:221-224.

165. Del Guidice E, Preparata G. Coherent electrodynamics in water. In: Schulte J, Endler PC, eds. Fundamental Research in Ultra High Dilution and Homeopathy. Dordrecht: Kluwer, 1998: 89-103.

166. Bernini A, Spiga O, Ciutti A, et al. On the dynamics of water molecules at the protein solute interfaces. Homeopathy 2004;92:199-202.

167. Hyland ME. A brief guide to extended network entanglement theory as a theory of healing and its empirical predictions. 
Forschende Komplementärmedizin und Klassische Naturheilkunde 2003;10:201-206.

168. Hyland ME, Lewith GT. Oscillatory effects in a homeopathic clinical trial: An explanation using complexity theory, and implications for clinical practice. Homeopathy 2002;91: $145-149$.

169. Milgrom LR. Patient-practitioner-remedy (PPR) entanglement: A qualitative, non-local metaphor for homeopathy based on quantum theory [part 1]. Homeopathy 2002;91: 239-248.

170. Milgrom LR. Patient-practitioner-remedy (PPR) entanglement: Part 2. Extending the metaphor for homeopathy using molecular quantum theory. Homeopathy 2003;92:35-43.

171. Milgrom LR. Patient-practitioner-remedy (PPR) entanglement: Part 3. Refining the quantum metaphor for homeopathy. Homeopathy 2003;92:152-156.

172. Milgrom LR: Patient-practitioner-remedy (PPR) entanglement: Part 4. Towards classification and unification of the different quantum models for homeopathy. Homeopathy 2004;93:34-42.

173. Milgrom LR: Patient-practitioner-remedy (PPR) entanglement: Part 6. Miasms revisited: Non-linear quantum theory as a model for the homeopathic process. Homeopathy 2004;93:154-158.

174. Milgrom LR: Patient-practitioner-remedy (PPR) entanglement: Part 8. "Laser-like" action of the homeopathic therapeutic encounter as predicted by a gyroscopic metaphor for the vital force. Forschende Komplementärmedizin und Klassische Naturheilkunde 2005;12:206-213.

175. Milgrom LR. The sound of two hands clapping: Could homeopathy work locally and non-locally? Homeopathy 2005;95: $100-104$.

176. Weingärtner O. Can we scientifically identify a "remedial content" of high potencies? [in German]. Forschende Komplementärmedizin und Klassische Naturheilkunde 2002;9: 229-233.

177. Walach H. Entanglement model of homeopathy as an example of generalised entanglement predicted by Weak Quantum
Theory. Forschende Komplementärmedizin und Klassische Naturheilkunde 2003;10:192-200.

178. Hyland ME. Entanglement and some heretical thoughts about homeopathy. Homeopathy 2005;94:105-106.

179. Walach H. Entangled - and tied in knots! Practical consequences of an entanglement model for homeopathic reserach and practice. Homeopathy 2005;94:96-99.

180. Walach H. Magic of signs: A non-local interpretation of homeopathy. Br Homeopathic J 2000;89:127-140.

181. Atmanspacher H, Römer H, Walach H. Weak quantum theory: Complementarity and entanglement in physics and beyond. Foundations Physics 2002;32:379-406.

182. Wackermann J, Seiter C, Keibel H, Walach H. Correlations between brain electrical activities of two spatially separated human subjects. Neurosci Lett 2003;336:60-64.

183. Walach H. Economy chased medicine: Monetarisation of health-chance or threat for complementary medicine? [in German]. Forschende Komplementärmedizin und Klassische Naturheilkunde/Research in Complementary and Classical Natural Medicine 2005;12:188-189.

184. Hyland ME. Extended network learning error: A new way of conceptualising chronic fatigue syndrome. Psychol Health 2001;16:273-287.

185. Hyland ME: The intelligent body and its discontents. J Health Psychol 2002;7:21-32.

Address reprint requests to: Harald Walach, Ph.D. University College Northampton School of Social Sciences Boughton Green Road Northampton NN2 7AL United Kingdom

E-mail:harald.walach@northampton.ac.uk 